Check for updates

Cite this: RSC Adv., 2020, 10, 25529

\title{
A multi-technique study of altered granitic rock from the Krunkelbach Valley uranium deposit, Southern Germany' $\dagger$
}

\author{
Ivan Pidchenko, (D) *ab Stephen Bauters, (D) ab Irina Sinenko, ${ }^{c}$ Simone Hempel, ${ }^{d}$ \\ Lucia Amidani, (iD ab Dirk Detollenaere, ${ }^{\text {eg }}$ Laszlo Vinze, (D) e Dipanjan Banerjee, (iD fg \\ Roelof van Silfhout, (DD h Stepan N. Kalmykov, (D) ${ }^{\text {c } J o ̈ r g ~ G o ̈ t t l i c h e r, ' ~ R o b e r t ~ J . ~ B a k e r ~(D D ~}$ \\ and Kristina $\mathrm{O}$. Kvashnina (D) *abc
}

Herein, a multi-technique study was performed to reveal the elemental speciation and microphase composition in altered granitic rock collected from the Krunkelbach Valley uranium (U) deposit area near an abandoned $U$ mine, Black Forest, Southern Germany. The former Krunkelbach U mine with 1-2 km surrounding area represents a unique natural analogue site with the rich accumulation of secondary $U$ minerals suitable for radionuclide migration studies from a spent nuclear fuel (SNF) repository. Based on a micro-technique analysis using several synchrotron-based techniques such as $\mathrm{X}$-ray fluorescence analysis, X-ray absorption spectroscopy, powder X-ray diffraction and laboratory-based scanning electron microscopy and Raman spectroscopy, the complex mineral assemblage was identified. While on the surface of granite, heavily altered metazeunerite-metatorbernite $\left(\mathrm{Cu}\left(\mathrm{UO}_{2}\right)_{2}\left(\mathrm{AsO}_{4}\right)_{2-x}\left(\mathrm{PO}_{4}\right)_{x} \cdot 8 \mathrm{H}_{2} \mathrm{O}\right)$ microcrystals were found together with diluted coatings similar to cuprosklodowskite $\left(\mathrm{Cu}\left(\mathrm{UO}_{2}\right)_{2}\left(\mathrm{SiO}_{3} \mathrm{OH}\right)_{2} \cdot 6 \mathrm{H}_{2} \mathrm{O}\right)$, in the cavities of the rock predominantly well-preserved microcrystals close to metatorbernite $\left(\mathrm{Cu}\left(\mathrm{UO}_{2}\right)_{2}\left(\mathrm{PO}_{4}\right)_{2} \cdot 8 \mathrm{H}_{2} \mathrm{O}\right)$ were identified. The $\mathrm{Cu}\left(\mathrm{UO}_{2}\right)_{2}\left(\mathrm{AsO}_{4}\right)_{2-x}\left(\mathrm{PO}_{4}\right)_{x} \cdot 8 \mathrm{H}_{2} \mathrm{O}$ species exhibit uneven morphology and varies in its elemental composition, depending on the microcrystal part ranging from well-preserved to heavily altered on a scale of $\sim 200 \mu \mathrm{m}$. The microcrystal phase alteration could be presumably attributed to the microcrystal morphology, variations in chemical composition, and geochemical conditions at the site. The occurrence of uranyl-arsenate-phosphate and uranyl-silicate mineralisation on the surface of the same rock indicates the signatures of different geochemical conditions that took place after the oxidative weathering of the primary $U$ - and arsenic (As)-bearing ores. The relevance of uranyl minerals to SNF storage and the potential role of uranyl-arsenate mineral species in the mobilization of $U$ and As into the environment is discussed.

Received 15th April 2020

Accepted 11th June 2020

DOI: 10.1039/d0ra03375h

rsc.li/rsc-advances mining and ore reprocessing activities. ${ }^{1-3}$ U-containing natural systems, e.g. ore bodies and former mining sites, are often considered as natural analogues for investigations of potential radionuclide release and retardation processes expected in representing a significant environmental hazard after the

${ }^{a}$ The Rossendorf Beamline at ESRF - The European Synchrotron, CS40220, 38043, Grenoble Cedex 9, France. E-mail: kristina.kvashnina@esrf.fr; ivan.pidchenko@ gmail.com

${ }^{b}$ Helmholtz-Zentrum Dresden-Rossendorf (HZDR), Institute of Resource Ecology, PO Box 510119, 01314 Dresden, Germany

${ }^{c}$ Lomonosov Moscow State University, Department of Chemistry, 119991 Moscow, Russia

${ }^{d}$ Technical University Dresden, Institute of Construction Materials, DE-01062 Dresden, Germany

${ }^{e}$ Department of Chemistry, X-ray Imaging and Microspectroscopy Research Group, Ghent University, Ghent, Belgium

${ }^{f}$ Department of Chemistry, KU Leuven, Celestijnenlaan 200F, Box 2404, B-3001 Leuven, Belgium
${ }^{g}$ Dutch-Belgian Beamline (DUBBLE), European Synchrotron Radiation Facility, 71 Avenue des Martyrs, CS 40220, 38043 Grenoble Cedex 9, France

${ }^{h}$ The University of Manchester, School of Electrical and Electronic Engineering, Sackville Street, Manchester M13 9PL, UK

${ }^{i}$ Karlsruhe Institute of Technology, Institute for Photon Science and Synchrotron Radiation (IPS), P.O. 3640, D-76021 Karlsruhe, Germany

${ }^{j}$ School of Chemistry, University of Dublin, Trinity College, Dublin 2, Ireland

$\dagger$ Electronic supplementary information (ESI) available: Selected $\mathrm{U} \mathrm{L}_{3}$ edge $\mu$-XANES spectra plotted without $Y$ axis offset, theoretical calculations for $\mathrm{U}_{3}$ edge HERFD-XANES spectra, microphotograph of the rock cavities revealing flat shaped green microcrystals, details for $\mathrm{U}_{3}$ edge HERFD-XANES measurements, $\mathrm{U} \mathrm{L}_{3}$ edge HERFD-XANES spectra collected from a whole rock, deconvolution of Raman spectrum, list of $U$ minerals identified in the Krunkelbach mine. See DOI: 10.1039/d0ra03375h 
a real spent nuclear fuel (SNF) repository. ${ }^{4}$ In this context, several mineralogical studies have focused on the alteration and oxidative corrosion processes of a primary $\mathrm{U}$ mineral, uraninite $\left(\mathrm{UO}_{2+x}\right)$, and SNF's components under ambient and extreme conditions. ${ }^{5-7}$ To assess the potential risks associated with the long-term storage and possible alteration of SNF, actinide- and lanthanide-containing systems have been intensively investigated to draw comparisons with analogue systems in a functional repository. ${ }^{8-10}$

Depending on the local geology and geochemical conditions, the alteration of uraninite results in the formation of various alteration products. Whilst the richest $U$ mineral families are (oxyhydr)oxides, carbonates and silicates, a smaller number of uranyl minerals are represented by selenates $\left(\mathrm{SeO}_{4}{ }^{2-}\right)$, arsenates $\left(\mathrm{AsO}_{4}{ }^{3-}\right)$ and phosphates $\left(\mathrm{PO}_{4}{ }^{3-}\right)$ occurring under oxidizing conditions. ${ }^{\mathbf{1 1}}$ Selenium (Se) and arsenic (As) are elements of environmental concern due to their high toxicity. ${ }^{\mathbf{1 2 - 1 6}}$ The formation of uranyl selenates and arsenates is mainly associated with oxidation processes of sulfide (S) minerals and acidification of groundwaters followed by the subsequent release of S, Se, As and other trace elements along with $\mathrm{U}$ from associated mineralisation. Thus, $\mathrm{U}, \mathrm{S}$, As and traces of Se were identified to be simultaneously present in the ore material from the former Krunkelbach mine in both unaltered and altered ores. ${ }^{17} \mathrm{U}$ and As are often associated together in organic-rich sediments where U occurs mainly as reduced U(IV) species, mine tailings and in abandoned mining sites after underground flooding activities. This causes additional hazards associated with the release of As into water aquifers. ${ }^{18-24}$ In cases when reduction conditions prevail, such as at the Ruprechtov site in the Czech Republic, As occurs in the form of arsenopyrite (FeAsS) in tertiary sediments forming layered aggregates with secondary uraninite and arsenopyrite. ${ }^{19}$ Mixed copper uranyl arsenate-phosphate species have been identified in the soils from an abandoned $\mathrm{U}$ mine in the UK as a result of many years of the mining activities at the site..$^{18,20}$ Based on the results of these investigations, As is assumed to control $\mathrm{U}$ mobility by the formation of a sparingly soluble metazeunerite solid solution $\left(K_{\mathrm{sp}}=10^{-49.2}\right)$. Indeed uranyl arsenates form compounds that have much lower solubility products compared to other uranyl phases, i.e. $\mathrm{U}$ (oxyhydr)oxides with $\mathrm{U}$ being often incorporated into Fe (oxyhydr)oxides $\left(K_{\mathrm{sp}}=10^{-37}-10^{-44}\right),{ }^{25}$ thus limiting $\mathrm{U}$ and As release into the environment. ${ }^{18,26}$ The occurrence of mixed phases with a small amount of phosphate substituting for arsenate was first discussed by Frondel. ${ }^{27}$ Recent studies of $\mathrm{U}$ mineralisation from hydrothermal type $U$ deposits in the Southern UK reported the occurrence of metazeunerite-metatorbernite species with a relatively high $\mathrm{P}$ content up to $\sim 20$ at\%. ${ }^{20}$ Mineralogical and chemical properties of such mixed phases, however, are still ill-defined. Therefore, studies of synthetic and natural species from different geological locations are necessary to provide additional information on the degradation properties of these compounds, i.e. phase dissolution, ion-exchange behavior depending on chemical composition and temperature, etc.

Both synchrotron and laboratory methods are extensively used separately and in combination for investigations of structural, redox and degradation properties of $\mathrm{U}$ minerals..$^{18,20,23,28-30}$ Whilst synchrotron methods provide robust and fast analysis with higher sample penetration depth for elemental mapping and speciation as low as few tens of ppm for some heavier metals, e.g. uranium, laboratory tools provide more detailed analysis of the sample's morphology and more detailed speciation. ${ }^{31-33}$ The use of the combined experimental approach is often preferred due to the intricate $U$ speciation in environmental systems, which helps to develop optimal strategies for contaminated site remediation..$^{34,35}$ For example, the detailed speciation analysis at U contaminated sites in Ohio, at Oak Ridge and Hanford Site in the USA made it possible to develop effective engineering campaigns for reducing the $\mathrm{U}$ content in groundwaters by in situ sorption-precipitation or by utilizing permeable reactive barriers. ${ }^{36-38}$

Rich secondary U mineralisation represents high environmental significance of the location due to possible degradation of these phases and further migration of contaminants in the environment. In this context, one of the aims of the study is to find the evidence for alteration of one of the potentially hazardous secondary $U$ phases using a combination of several techniques. To achieve this, we utilized a multitude of spectroscopic techniques that are both laboratory- and synchrotronbased. We first describe our characterisation efforts, and then put these into the context of SNF storage in a geological repository. Herein, we demonstrate how a combination of synchrotron and laboratory tools can be effectively utilized for the analysis of the crystalline environmental samples without any complicated sample preparation procedure. As a case study, we performed the elemental and microphase speciation on an altered granite rock collected near an abandoned $U$ mine in Southern Germany. Micro-X-ray fluorescence ( $\mu$-XRF) coupled with $\mathrm{U} \mathrm{L}_{3}$ edge micro-X-ray absorption near-edge structure $(\mu$ XANES) spectroscopy and micro-powder X-ray diffraction $(\mu-$ PXRD) analyses, and laboratory Raman and scanning electron microscopy (SEM) with energy-dispersive X-ray (EDX) spectroscopic techniques used for the investigation of complex microphase U-mineral assemblages are highlighted.

\section{Materials and methods}

\section{A. Sample description}

For our study, a sample material $\left(\sim 5 \times 5 \times 10 \mathrm{~mm}^{3}\right)$ was collected near the Krunkelbach Valley uranium deposit (Fig. 1) in the 1980s during underground mining works and later stored in a mineral collection. It was originally described as a two-mica granite rock, Bärhalde granite, together with quartz $\left(\mathrm{SiO}_{2}\right), \mathrm{U}$ silicates - soddyite $\left(\left(\mathrm{UO}_{2}\right)_{2} \mathrm{SiO}_{4} \cdot 2 \mathrm{H}_{2} \mathrm{O}\right)$, redox mixed $\mathrm{U}$ (oxyhydr) oxide - ianthinite $\left(\mathrm{U}^{4+/ 5+}\left(\mathrm{UO}_{2}\right)_{5} \mathrm{O}_{7} \cdot 10 \mathrm{H}_{2} \mathrm{O}\right)$ and $\mathrm{Fe}$ (oxyhydr) oxide - goethite $(\alpha-\mathrm{FeO}(\mathrm{OH}))$, forming a pseudomorph after ianthinite on the surface of a rock. The Krunkelbach U deposit is a hydrothermal vein-type deposit with late Carboniferous formation age of $295 \pm 7 \mathrm{Ma}$ and the age of secondary U mineralisation estimated at $300 \pm 50 \mathrm{ka}^{39}$ The pilot exploration took place in the 1960 s by shaft mining and $U$ reserves estimated at 1000 tons of $\mathrm{U}_{3} \mathrm{O}_{8}$ at an average grade of $0.7 \mathrm{wt} \%$ (see geological map in Fig. 1). ${ }^{22,40}$ The host rock of the deposit is 

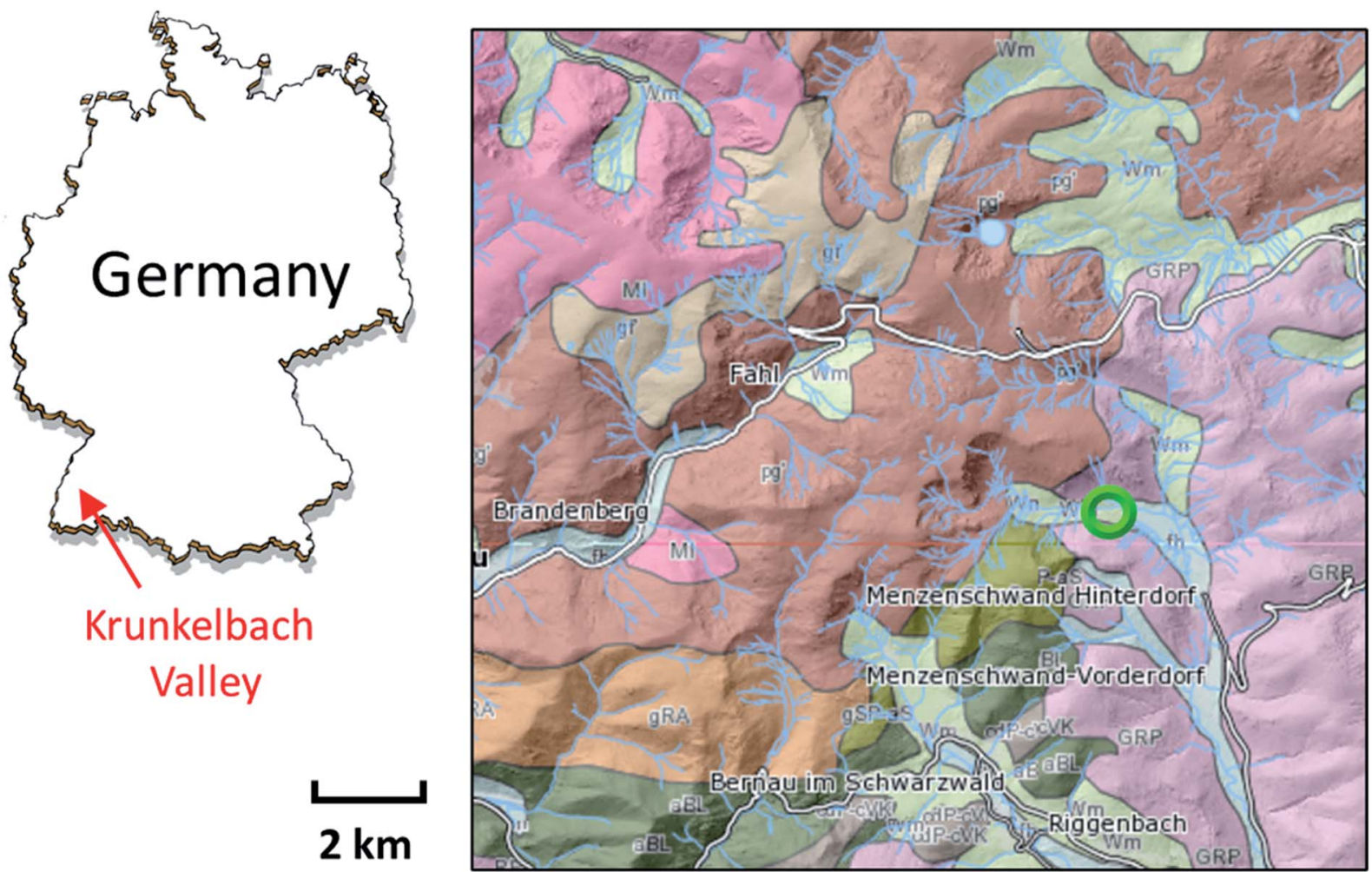

Fig. 1 Location of the Krunkelbach Valley $U$ deposit, Menzenschwand, Baden-Württemberg, Southern Germany (marked with a green circle). A geological relief map of the site is retrieved from the database of the Geological Survey of Germany (https://www.maps.lgrb-bw.de). The Krunkelbach Valley is situated mainly on the flood sediments (fh, light blue) on the border with paragneiss (pg', brown region), granite plutons (GRP, light-pink region) and Würm-moraine sediments (Wm, light green).

highly altered down to $240 \mathrm{~m}$, which is due to the continuous interaction of the rock with intruding oxygenated ground waters, causing the formation of secondary $\mathrm{U}$ and $\mathrm{Fe}$ mineralization.

The sample was first analysed using a Carl Zeiss STEMI 2000C stereomicroscope to select suitable parts and microcrystals for further investigations. The rock part containing several green microcrystals initially not described was subsequently selected for the bulk $\mu$-XRF and $\mathrm{U} \mathrm{L}_{3}$ edge $\mu$-XANES analysis.

\section{B. Synchrotron $\mu$-XRF coupled with $U L_{3}$ edge $\mu$-XANES spectroscopy}

The $\mu$-XRF and $\mathrm{U} \mathrm{L}_{3}$ edge $\mu$-XANES measurements were performed at the DUBBLE BM26A beamline of the European Synchrotron Radiation Facility (ESRF).$^{41}$ The incident energy was selected using a double $\mathrm{Si}(111)$ crystal monochromator. Rejection of higher harmonics was achieved with two Pt mirrors at an angle of $2 \mathrm{mrad}$ relative to the incident beam. The dedicated micro-focus platform provided an $8 \times 8 \mu \mathrm{m}^{2}$ spot size at the sample position. XRF mappings were recorded at $17177 \mathrm{eV}$ with a $1 \mathrm{~s}$ dwell time and $20 \mu \mathrm{m}$ step size. A $20 \mu \mathrm{m}$ step size was found optimal based on the preliminary sample analysis using a stereomicroscope. $\mathrm{U} \mathrm{L}_{3}$ edge $\mu$-XANES spectra were recorded on nine different spots on the area of $1.5 \times 2.5 \mathrm{~mm}^{2}$. Several spectra were recorded at each selected spot for each reference sample: metazeunerite (U-As), metatorbernite (U-P) and cuprosklodowskite (U-Si). All measurements have been performed under ambient conditions.

\section{C. $\mu$-PXRD}

The $\mu$-PXRD patterns were collected at the SUL-X beamline of a KIT synchrotron radiation source. Measurements were performed in transmission mode with beam size at the sample position of about $150 \times 150 \mu^{2}$ on grains using a CCD detector (Photonic Science XDI VHR-2 150). The beamline was operated at an energy of $17000 \mathrm{eV}$. The $D$ values were calibrated with $\mathrm{LaB}_{6}$ (NIST, 660b) (2 theta values correspond to $\lambda=0.729684 \AA$ after calibration). Measurements were performed under ambient conditions. Data analysis was performed using the FIT2D program and DIFFRAC.EVA V4.3 (Bruker). ${ }^{42}$

\section{Raman spectroscopy}

Raman measurements were conducted at room temperature using a LabRam ARAMIS (Horiba Jobin Yvon) at an excitation wavelength of $532 \mathrm{~nm}$ (Nd:YAG). The machine was calibrated using a silicon wafer with the first-order Si line at $520.7 \mathrm{~cm}^{-1}$. For all measurements, an 1800 lines per mm diffraction grating was used with a slit of $100 \mu \mathrm{m}$, a hole of $300 \mu \mathrm{m}$, and a neutral density filter $D 0.3$ (50\% transparency), respectively. 


\section{E. SEM-EDX}

The SEM-EDX investigations were performed at Technical University Dresden using a QUANTA 250 FEG (FEI) microscope in LowVac mode combined with an EDX-system QUANTAX 400 (Bruker). The software Esprit 2.1 was used to evaluate the EDX data.

\section{Results}

A. Elemental and microphase analysis by $\mu$-XRF and $\mu$-PXRD

Attempts to detect needle-shaped violet ianthinite microcrystals initially described on the rock were not successful. Instead, several tiny platy-shaped vitreous green crystals were identified using an optical microscope on the surface and in the cavities of the sample. The $\mu$-XRF element mapping distinguished regions of different sets of elements with varying signal intensities and areas. $\mathrm{U}$ and As were identified in concentrated regions that are associated with $\mathrm{Cu}$ (Fig. 2a, right column: EDX data with $\mathrm{Cu}-\mathrm{U}-$ As RGB mapping). Less intense regions showed the occurrence of $\mathrm{Cu}, \mathrm{Fe}, \mathrm{Pb}$ and $\mathrm{W}$. The latter three showed no correlation with $\mathrm{U}$ and $\mathrm{As}$ in the intensive signal regions (see left column XRF on Fig. 2a) followed by $\mu$-XANES analysis (Fig. 2b). The occurrence of $\mathrm{Cu}, \mathrm{U}$ and As agreed with copper-bearing uranyl arsenate, phase corresponding to (meta)zeunerite $\left(\mathrm{Cu}\left(\mathrm{UO}_{2}\right)_{2}\left(\mathrm{AsO}_{4}\right)_{2}\right.$ $\cdot 8-12 \mathrm{H}_{2} \mathrm{O}$ ), one of the most common $\mathrm{U}$ mineralisations at the Krunkelbach site. ${ }^{43}$ The metazeunerite species (see Fig. 3a) were further confirmed by $\mu$-PXRD on green crystals selected from the surface of the rock (Fig. 3b). The presence of $\mathrm{W}, \mathrm{Bi}, \mathrm{Pb}$, and minor Ba indicated a possible occurrence of two relatively rare $\mathrm{U}$ species: uranotungstite $\left((\mathrm{Fe}, \mathrm{Ba}, \mathrm{Pb})\left(\mathrm{UO}_{2}\right)_{2}\left(\mathrm{WO}_{4}\right)(\mathrm{OH})_{4} \cdot 12 \mathrm{H}_{2} \mathrm{O}\right)$ and walpurgite $\left((\mathrm{BiO})_{4}\left(\mathrm{UO}_{2}\right)\left(\mathrm{AsO}_{4}\right)_{2} \cdot 2 \mathrm{H}_{2} \mathrm{O}\right)$. Both species were previously identified in the Krunkelbach and Schneeberg $\mathrm{U}$ deposits, respectively. ${ }^{\mathbf{4 0 , 4 4}}$ In the Schneeberg deposit, walpurgite is described to occur together with metazeunerite species.
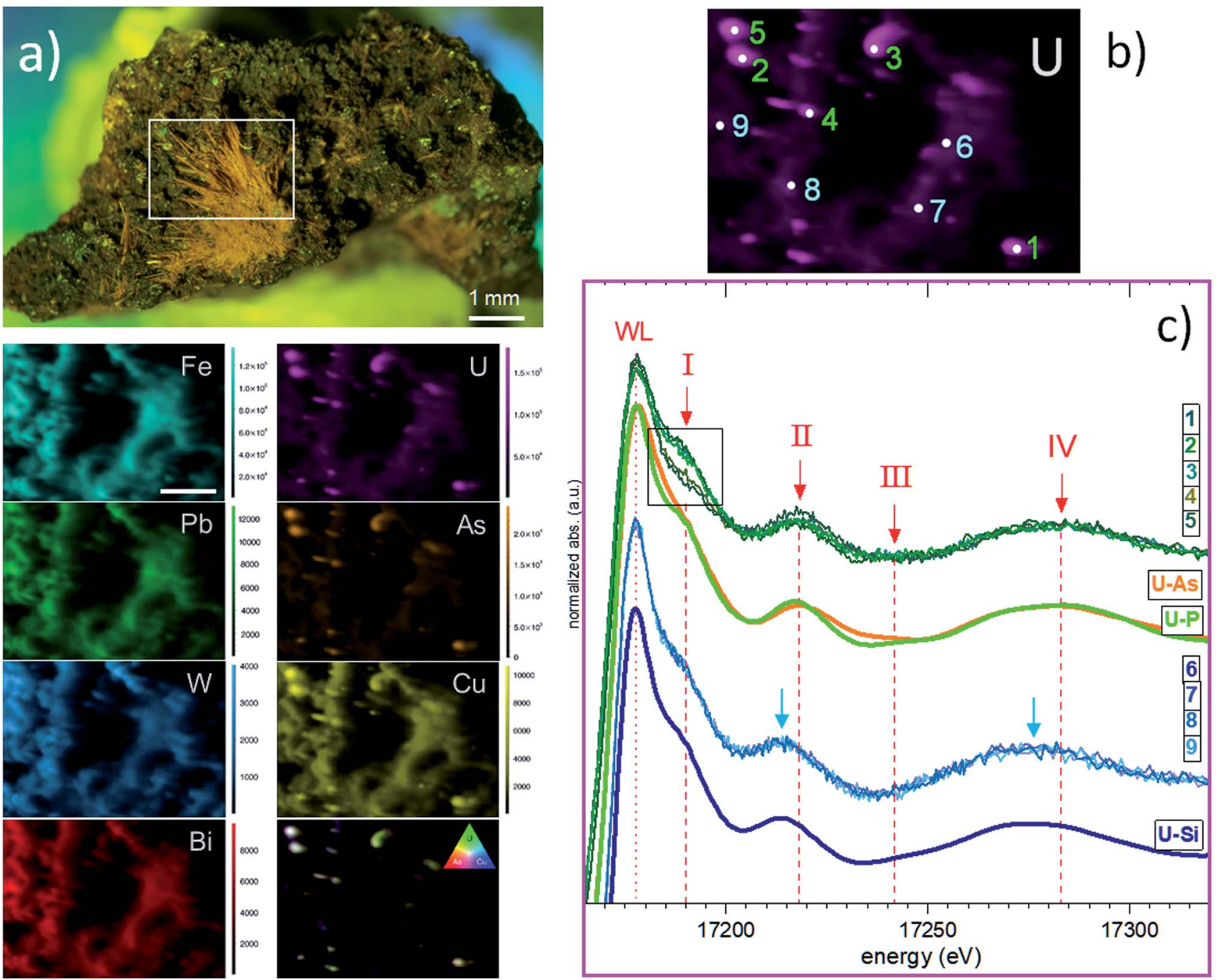

Fig. 2 Photograph of the rock sample with the outlined region $\left(2.5 \times 1.5 \mathrm{~mm}^{2}\right)$ selected for $\mu$-XRF/ $\mu$-XANES analysis includes fibrous goethite aggregates mixed with green microcrystals, $\mu$-XRF based element mapping (left column: Fe, Pb, W, Bi; right column: U, As, Cu and RGB map for $U, A s, C u$ ), scale bar shown at $1 \mathrm{~mm}(a) ; U \mu$-XRF map with nine spots selected for $\mu$-XANES analysis (b); $U L_{3}$ edge $\mu$-XANES spectra recorded on spots selected from $U \mu$-XRF map, spectra of metatorbernite $(U-P)$, metazeunerite $(U-A s)$ and cuprosklodowskite $(U-S i)$ reference samples (c). 

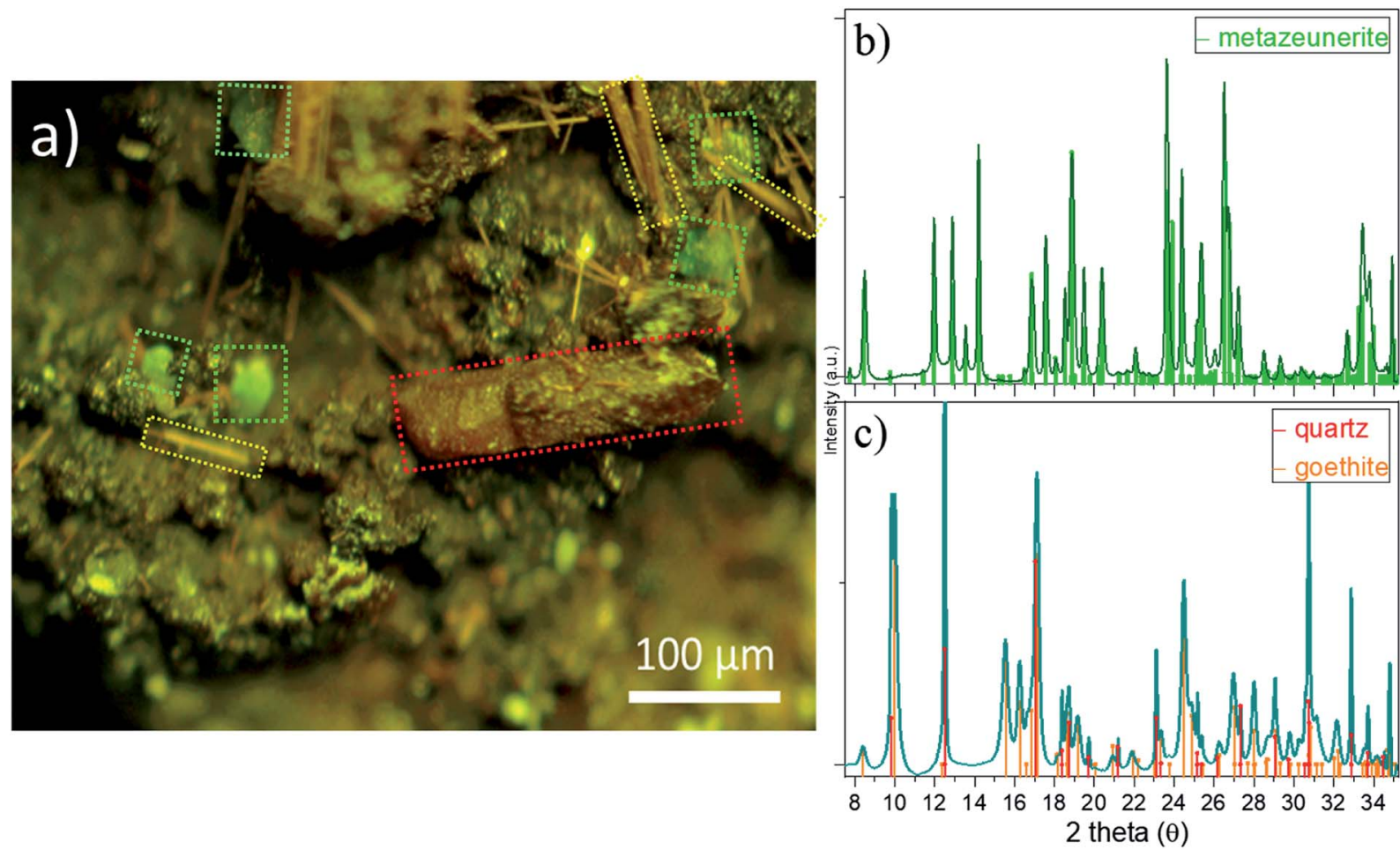

Fig. 3 Microphotograph of the surface: green crystals of metazeunerite, dark-brown quartz, and light-brown, needle-shaped goethite crystals (a); $\mu$-PXRD patterns of green crystals selected from the surface of the granitic rock and database metazeunerite (ICDD - 40148463) (b); and light- and dark-brown crystals correspond to goethite (ICDD - 290713) and quartz (ICDD - 0898935), respectively (c).

Considering that the XRF measurement is limited to minimum energy of $\sim 6 \mathrm{keV}$ due to photon self-absorption in air, the detection of some elements, i.e. $\mathrm{Na}, \mathrm{K}, \mathrm{P}, \mathrm{Al}, \mathrm{Si}$, etc., is hindered. Hence, the possible presence of another U-As mineral phase nielsbohrite $\left.\left(\mathrm{K}_{\left(\mathrm{UO}_{2}\right.}\right)_{3}\left(\mathrm{AsO}_{4}\right)(\mathrm{OH})_{4} \cdot \mathrm{H}_{2} \mathrm{O}\right)$, reported for the Krunkelbach deposit cannot be excluded. ${ }^{45}$ Other microphases identified on the rock correspond to quartz and goethite (Fig. 3c). No U species were found associated with goethite needles. The energy-dispersive X-ray (EDX) analysis of selected goethite microcrystals did not detect any U assuming its pseudomorphic nature. In previously reported studies, $\mathrm{U}$ is found incorporated into a goethite ore as a result of the oxidation and dissolution/reprecipitation events in a U deposit. ${ }^{17}$ Similarly, the correlation of $U$ with Fe minerals, metatorbernite and akaganeite $(\beta-\mathrm{FeO}(\mathrm{OH}))$, was identified in the soils after intensive $\mathrm{U}$ mining activities in the Southern UK. ${ }^{18}$

\section{B. U speciation by $U L_{3}$ edge $\mu$-XANES}

Based on the $U \mu$-XRF map (see Fig. $2 b$ ), $U L_{3}$ edge $\mu$-XANES spectra were recorded on two different regions exhibiting varying $U$ intensity: five selected spots with higher $U$ contents (marked 1-5) and four zones exhibiting less intense U signals (marked 6-9) (Fig. 2c). To compare these sets of spectra, we marked four spectral features as I, II, III and IV within $\sim 100 \mathrm{eV}$ range, above the white line (WL). The intensity of the WL differs for two sets of spectra and exhibits a higher intensity for the spectra collected from the zones with low U signals (6-9). All spectra recorded for these $\mathrm{U}$ zones are identical and fit well with the spectrum of cuprosklodowskite. The latter is described as one of the uranyl silicate minerals occurring in the Krunkelbach deposit. ${ }^{40}$ The collected spectra show distinct signatures in the energy position for all spectral features (see Fig. S1 $\dagger$ ). Feature I, referred to multi-scattering paths at the uranyl moiety, exhibits different shapes and intensities depending on the measured zone and exact spot. Feature I reveals a lower intensity in spectra 1 and 4, it is significantly more intensive in spectra 2, 3 and 5, thus providing the first signature of different $U$ speciations for high-intensity U spots (see inlet box in Fig. 2 c). ${ }^{46}$ Features II, III and IV are more sensitive to close local atomic environment around $\mathrm{U}$ atoms, i.e. U-O equatorial bonding, and can be used as a relative measure of uranyl-ligand bonding characteristics in studied species. Thus, features II and IV for spectra 6-9 are shifted $\sim 4-5 \mathrm{eV}$ to the lower energy compared to spectra 1-5 (see Fig. 2c). The similarity of spectra 1-5 with the reference spectra of metazeunerite and metatorbernite and agreement with the XRF analysis results show that the analysed species are related to these two references. Both metazeunerite and metatorbernite species have been previously described in the Krunkelbach $\mathrm{U}$ mine, with metazeunerite being the most common secondary $\mathrm{U}$ mineral in the area. ${ }^{43}$ Metazeunerite and metatorbernite are isostructural minerals with minor differences in crystallographic parameters. This example demonstrates that $\mu$ XANES is a powerful tool, which allows for the fingerprinting analysis in cases when the properly defined references can be used (see theoretically modeled spectra on Fig. S2 $\dagger$ ). 
Additionally, the whole rock sample has been analysed by $\mathrm{U}$ $\mathrm{L}_{3}$ edge HERFD-XANES spectroscopy (see $\mathrm{ESI} \dagger$ for technique description). ${ }^{47}$ The technique, in general, provides much better resolved spectral features, allowing for significantly more detailed analysis of $U$ redox state especially for environmentally relevant systems, where $U$ can be stabilized as a mixture of two or even three redox states, namely, U(Iv), U(v) and $\mathrm{U}(\mathrm{vI})$, and more detailed structural characterization. ${ }^{48-50}$ The collected spectra were recorded with a relatively large beam size, $\sim 100 \times$ $400 \mu^{2}$, and likely HERFD probes simultaneously several $\mathrm{U}$ phases (Fig. S4 $\dagger$ ). However, our data show the capacity of HERFD for future investigations, especially in cases when HERFD can be recorded with an X-ray beam size of 1-5 $\mu \mathrm{m}$. It is important to mention that the detection limit for $\mathrm{U}$, and As and other heavy metals, depends on the synchrotron source and beamline. While systems with few hundred ppm $U$ can be analysed at most of the synchrotrons, a sub-ppm detection limit can be achieved for some heavy metals at superior beamlines. ${ }^{51}$

\section{Evidence of metazeunerite-metatorbernite occurrence and heterogeneous alteration by Raman and SEM-EDX spectroscopy}

To reveal the signatures of possible occurrence of minor uranyl microphases, we used Raman spectroscopy. Raman spectroscopy takes advantage of fast speciation analysis due to the unique positions of the vibrational bands for metals and ligands. ${ }^{\mathbf{2 0 , 2 8}}$ The analysis of microcrystals selected from the surface and the cavity of the rock (see Fig. 4 and S3†) revealed clear signatures in $\mathrm{U}$ speciation. Raman spectra exhibited vibrational bands characteristic of uranyl $\left(\mathrm{UO}_{2}{ }^{2+}\right)$, arsenate $\left(\mathrm{AsO}_{4}{ }^{3-}\right)$ and phosphate $\left(\mathrm{PO}_{4}{ }^{3-}\right): 326 \mathrm{~cm}^{-1}$ corresponds to $\nu_{2}\left(\mathrm{AsO}_{4}{ }^{3-}\right)$, and $404 \mathrm{~cm}^{-1}$ and $458 \mathrm{~cm}^{-1}$ correspond to $\nu_{4}\left(\mathrm{AsO}_{4}{ }^{3-}\right)$ and $\nu_{4}\left(\mathrm{PO}_{4}{ }^{3-}\right)$ bending modes, respectively (Fig. 4a). ${ }^{20}$ A double peak was distinguished for ' $r 2$ ' at $\sim 440 \mathrm{~cm}^{-1}$ and $\sim 460 \mathrm{~cm}^{-1}$. While the first peak was characteristic of $\nu_{2,4}\left(\mathrm{PO}_{4}{ }^{3-}\right)$, the second peak arising at $\sim 460 \mathrm{~cm}^{-1}$ was likely more sensitive to $\nu_{4}\left(\mathrm{AsO}_{4}{ }^{3-}\right)$ bending vibration. ${ }^{20}$ No information on the peak detected at $\sim 493 \mathrm{~cm}^{-1}$ was found in the available literature. The most intense and typical bands arising at $817-823 \mathrm{~cm}^{-1}$ originated from the $\nu_{1}\left(\mathrm{UO}_{2}{ }^{2+}\right)$ symmetric stretching vibration (Fig. 4b). Two less intense bands at $892 \mathrm{~cm}^{-1}$ corresponded to $\nu_{3}\left(\mathrm{UO}_{2}{ }^{2+}\right)$ antisymmetric stretching vibration in metazeunerite (' $\mathrm{r} 1$ ') and $992 \mathrm{~cm}^{-1}$ to $\nu_{3}\left(\mathrm{PO}_{4}{ }^{3-}\right)$ in metatorbernite, respectively. ${ }^{\mathbf{2 0 , 2 8}}$ Another weak vibrational band normally resolved in metatorbernite $900-905 \mathrm{~cm}^{-1}$ was attributed to $\nu_{3}\left(\mathrm{UO}_{2}{ }^{2+}\right)$ stretching vibration. Some broadening of the $\nu_{1}\left(\mathrm{UO}_{2}{ }^{2+}\right)$ band in both spectra might be a result of the overlapping with $\nu_{1}\left(\mathrm{AsO}_{4}{ }^{3-}\right)$ at $815 \mathrm{~cm}^{-1} \cdot{ }^{26}$ Analysis of the Raman spectra for different natural metazeunerite mineral species summarized in the RRUFF database gives average $\nu_{1}\left(\mathrm{UO}_{2}{ }^{2+}\right)=815 \mathrm{~cm}^{-1,52}$ and agrees with our value, $817 \mathrm{~cm}^{-1}$. Some shifts of the frequencies could be attributed to the presence of $\mathrm{AsO}_{4}{ }^{3-}$ and/or other fractions in each species and settings of the Raman spectrometer. The evidence that $\mathrm{PO}_{4}{ }^{3-}$ might be present in ' $\mathrm{r} 2$ ' is supported by a spectrum feature distinguishable at $\sim 825-830 \mathrm{~cm}^{-1}$ and by an additional band arising at $992 \mathrm{~cm}^{-1}$, characteristic of $\mathrm{PO}_{4}{ }^{3-}$. Deconvolution of 'r2' spectrum gives two peaks at $817 \mathrm{~cm}^{-1}$ and $827 \mathrm{~cm}^{-1}$, which agree well with the $\nu_{1}\left(\mathrm{UO}_{2}{ }^{2+}\right)$ values of metazeunerite and metatorbernite, respectively (Fig. $\mathrm{S} 5 \dagger$ ). ${ }^{28,53}$

SEM-EDX analysis performed on $\sim 200 \mu \mathrm{m}$ green crystals selected from the surface of the rock showed the presence of major elements: $\mathrm{Cu}, \mathrm{U}$, As and P with traces of Si and Fe (Fig. 5, Table 1). SEM reveals two discrete parts, a well-preserved part with a clearly defined pyramidal part with a terminated top plane, and a heavily corroded part without any distinguishable shape. Dark grey parts detected on the SEM image belong to goethite debris as well as lighter parts from quartz. EDX analysis of four different microcrystal parts shows the highest variation in As and $\mathrm{P}$ contents around all analysed spots (see Table 1). The part around spot ' 1 ' belongs to a well-preserved crystal part, while '2-3-4' are presumably from the overgrown layer, based on O XRF mapping, with heavily corroded part around spots ' 3 ' and ' 4 '. The most significant variation in elemental composition was found for major elements, $\mathrm{Cu}, \mathrm{U}$, As and P, analysed in '2'and ' 4 '. The latter was associated with a decrease in the $\mathrm{U}$ and $P$ contents and a double fold increase in the As content close to that for the theoretical composition of metazeunerite (Table 1).

\section{Discussion}

The Krunkelbach area represents a potentially rich source of As originating mainly from the zeunerite reported as the main secondary $\mathrm{U}$ mineral species occurring at the site with several individual U-As species described elsewhere (see Table S1 and Fig. S6 $\dagger$ ). ${ }^{22}$ The formation of metazeunerite and metazeuneritemetatorbernite species is likely to take place after oxidative leaching of uraninite, arsenopyrite, chalcopyrite $\left(\mathrm{CuFeS}_{1-2}\right)$, enargite $\left(\mathrm{Cu}_{3} \mathrm{AsS}_{4}\right)$, and tennantite $\left(\mathrm{Cu}_{12}(\mathrm{Zn}, \mathrm{Fe})_{2} \mathrm{As}_{4} \mathrm{~S}_{13}\right)$ as potential sources of $\mathrm{As}$ and $\mathrm{Cu}$. Phosphorus is released from the host rocks once slightly acidic or close-to-neutral conditions prevail $(\mathrm{pH} \leq 7) \cdot{ }^{22,44}$ Uranyl silicates are precipitated earlier from groundwaters under slightly alkaline conditions, resulting in a more complex $U$ mineralisation..$^{\mathbf{5 4 , 4 4}}$ The knowledge of degradation properties for these environmentally relevant compounds is scarce. The correlation between $U$ and As assumes that the complexation would strongly affect the geochemistry of these two elements. The stability of uranylarsenates can be understood in terms of paragenesis of $\mathrm{U}$ minerals, where U-As together with structurally identical U phosphates form complexes exhibiting extremely low solubility and, thus, high stability to groundwaters. ${ }^{54}$ Owing to their low solubilities, U-P and U-As are considered important phases controlling $U$ speciation in the near-surface environment as well as $U$ mobility in natural systems, including different types of groundwaters. ${ }^{55,56}$ Although U-P is one of the most widespread and abundant environmental species, i.e. metatorbernite, the data about U-As phases are limited to some extent. Additional limitations in assessing the geochemical behavior of U-As systems are also due to the lack of reliable thermodynamic data for $\mathrm{pH}>6 .^{57}$

The $\mathrm{U}$ concentration in groundwaters in some of the Krunkelbach mine's sections has been analysed to range from $\mathrm{ppb}$ to 


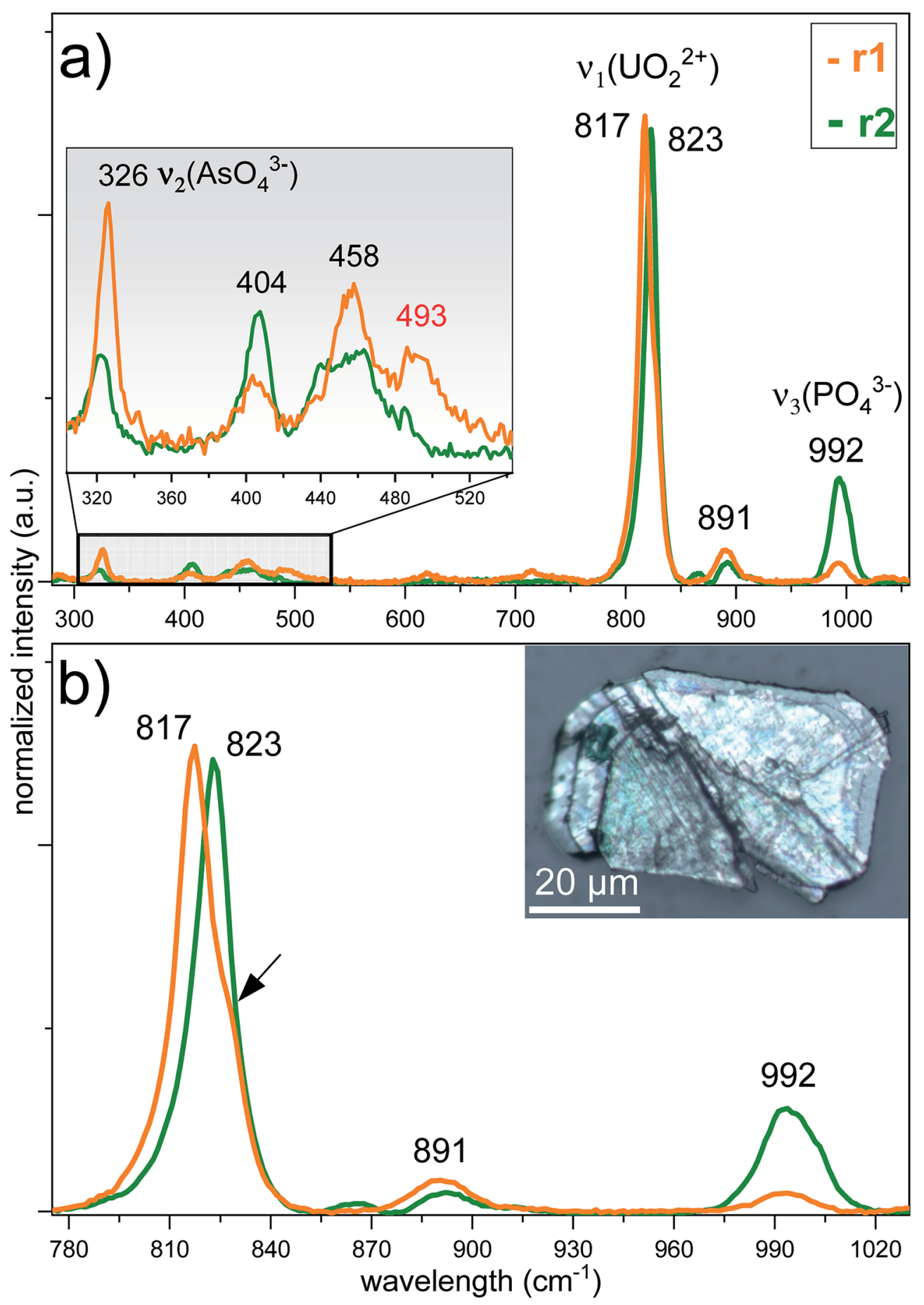

Fig. 4 Raman spectra of two different green crystals selected from the surface (' $r 1$ ', analysed by $\mu$-PXRD corresponds to metazeunerite) and from the cavity ('r2') of the rock with zoomed $290-550 \mathrm{~cm}^{-1}$ region (a); Raman spectra for the $780-1020 \mathrm{~cm}^{-1}$ region. Image of the $\sim 50 \mu \mathrm{m}$ size flat-shaped microcrystal selected from rock's cavity done with Raman spectrometer for ' $r 2$ '. Arrow indicates on the spectral feature in ' $r 1$ ' presumably referring to $U$-phosphate phase (b).

a few ppm U level. The sharp increase in the $\mathrm{U}$ concentration is attributed to the oxidation of the uraninite after the intrusion of oxygenated groundwater. ${ }^{17}$ The analysis of available data for $\mathrm{U}$ distribution in groundwaters and tap waters shows high median $\mathrm{U}$ contents in tap water at $0.76 \mu \mathrm{g} \mathrm{L}^{-1}$ for the region of Baden-Württemberg in Southern Germany. ${ }^{58}$ The elevated As content is reported in regions of Bad Herrenalb and BadenBaden, where thermal and groundwaters mobilize As from sediments and minerals. ${ }^{59} \mathrm{~A}$ region of Baden-Baden is known for the occurrence of the rich $\mathrm{U}-\mathrm{As}$ mineralisation, i.e. metakirchheimerite $\left(\mathrm{Co}\left(\mathrm{UO}_{2}\right)_{2}\left(\mathrm{AsO}_{4}\right)_{2} \cdot 8 \mathrm{H}_{2} \mathrm{O}\right)$, as one of the potential sources of both $\mathrm{U}$ and As the groundwaters. ${ }^{43}$ 

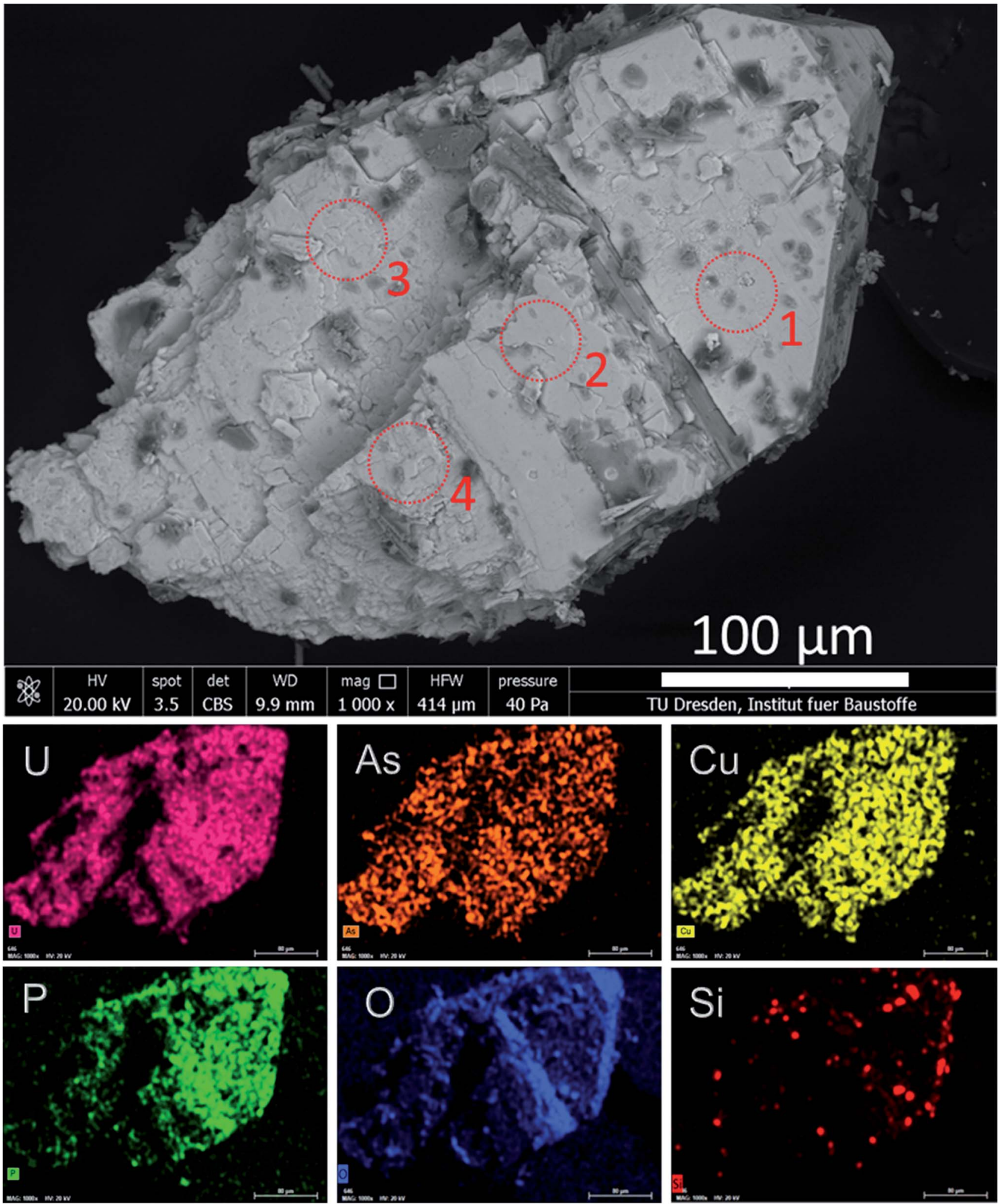

Fig. 5 SEM-EDX analysis for a green microcrystal selected from the surface of the granite rock. Dark grey areas on the SEM image correspond to Fe from the goethite debris. Red dotted circles show the spots at which EDX measurements were performed (Table 1).

The Krunkelbach deposit has exceptionally rich U mineralogy with more than 40 secondary $U$ mineral species described at a relatively small area of the $240 \mathrm{~m}$ deep mine and the surrounding area (see Table S1 and Fig. S6 $\dagger$ ). The mineral phases include uraninite, uranyl peroxide studtite ([( $\left.\mathrm{UO}_{2}\right)(-$ $\left.\left.\left.\mathrm{O}_{2}\right)\left(\mathrm{H}_{2} \mathrm{O}\right)_{2}\right] \cdot \mathrm{H}_{2} \mathrm{O}\right)$, and ianthinite. ${ }^{60,61}$ The latter is considered as 
Table 1 EDX semi-quantitative analysis of a green microcrystal (values normalized to $100 \%$ and values given in wt\%, EDX sensitivity for $U$ is estimated at $0.1 \mathrm{wt} \%$, deviation $\pm 1 \sigma$, n.d. - value not determined). Theoretical composition for metatorbernite ( $\mathrm{mt}$ ) and metazeunerite (mz)

\begin{tabular}{llllll}
\hline Analyzed part & $\mathrm{Cu}$ & $\mathrm{U}$ & $\mathrm{As}$ & $\mathrm{P}$ & $\mathrm{O}$ \\
\hline 1 & $8.9 \pm 0.6$ & $52.3 \pm 1.5$ & $11.8 \pm 1.0$ & $2.8 \pm 0.2$ & $24.2 \pm 4.7$ \\
2 & $7.5 \pm 0.7$ & $55.8 \pm 2.3$ & $7.8 \pm 0.6$ & $2.1 \pm 0.3$ & $26.8 \pm 7.2$ \\
3 & $9.3 \pm 0.6$ & $55.9 \pm 1.9$ & $10.9 \pm 1.1$ & $0.9 \pm 0.1$ & n.d. \\
4 & $11.5 \pm 0.6$ & $49.2 \pm 1.7$ & $14.1 \pm 0.8$ & $0.8 \pm 0.1$ & n.d. \\
$\mathrm{mt}$ & 6.78 & 50.77 & 0 & 6.61 & $24.3 \pm 4.2$ \\
$\mathrm{mz}$ & 6.2 & 46.42 & 14.61 & 0 & 34.12 \\
\end{tabular}

an important intermediate species in the paragenesis of $\mathrm{U}$ minerals and proposed as a potential mineral phase capable of hosting IV-V valent $\mathrm{An}$, i.e. $\mathrm{Pu}(\mathrm{IV})$ and $\mathrm{Np}(\mathrm{v}) .{ }^{61}$ The oxidation of uraninite is related to penetration oxygenated water from the water-bearing fractures resulting in the formation of numerous secondary uranyl species. The oxidation processes are estimated to begin 250-350k y ago and continue up to date, causing a loss of up to $10 \%$ of initial $U$ inventory. ${ }^{17,22}$ The location may be therefore considered as a potential natural analogue site for an operational SNF repository for which safety requirements imply safe storage of the SNF material for more than $100 \mathrm{k}$. The detailed knowledge of the geological history, geochemistry and degradation properties of secondary $U$ phases are therefore crucial for the assessment of the suitability of the geological sites for long-term SNF storage. The mineralogy of SNF will ultimately determine its durability to self-irradiation effects, and chemical corrosion with subsequent release of the radionuclides. Under specific geochemical conditions, uranyl phases might serve as solubility controls restricting $U$ migration even when present in highly mobile $\mathrm{U}(\mathrm{vI})$ form. ${ }^{18,34}$ During the investigation of the Krunkelbach $U$ deposit both unaltered and altered ores analysed for the As content showed minor release from initially estimated $\sim 1200 \mathrm{ppm}$ As content in unaltered rock. ${ }^{17}$ However, much more soluble uranyl phosphate species are reported to restrict $\mathrm{U}$ removal by the formation of several earth-alkaline uranyl phosphates, i.e. uranocircite $\left(\mathrm{Ba}\left(\mathrm{UO}_{2}\right)_{2}(-\right.$ $\left.\mathrm{PO}_{4}\right)_{2} \cdot 8 \mathrm{H}_{2} \mathrm{O}$ ) due to higher phosphorus mobility released after oxidative weathering from the related rocks. ${ }^{22} \mathrm{~A}$ minor loss of $\mathrm{P}$ and As here was associated with the high release of $U$ owing to its oxidative leaching as a geochemically mobile U(vI) species. The retardation of the mobilized $U$ has been identified on clay colloids and Ba-phosphate minerals and through precipitation of individual $\mathrm{U}(\mathrm{vI})$ mineral species.

More generally, depending on specific geochemical conditions, U(vI) minerals are important species controlling mobility of actinides at ore reprocessing and mining sites. Uranyl silicates, uranophane $\left(\mathrm{Ca}\left(\mathrm{UO}_{2}\right)_{2}\left(\mathrm{SiO}_{3} \mathrm{OH}\right)_{2} \cdot 5 \mathrm{H}_{2} \mathrm{O}\right)$ and cuprosklodowskite and metatorbernite group of minerals are reported to control $\mathrm{U}$ speciation at the contaminated Hanford and Oak Ridge sites ${ }^{36,62,63}$ Similarly, uranophane and haiweeite $\left(\mathrm{Ca}\left(\mathrm{UO}_{2}\right)_{2} \mathrm{Si}_{5} \mathrm{O}_{12}(\mathrm{OH})_{2} \cdot 3 \mathrm{H}_{2} \mathrm{O}\right)$ were found to determine $\mathrm{U}$ mobility at the Forsmark, a proposed host for radioactive waste repositories in Sweden. ${ }^{64}$ In another hydrothermal type U deposit in Southern France, U was found in weathered waste rocks to occur as uranyl phosphate comparable to autunite $\left(\mathrm{Ca}\left(\mathrm{UO}_{2}\right)_{2}\left(\mathrm{PO}_{4}\right)_{2} \cdot 10-12 \mathrm{H}_{2} \mathrm{O}\right)$ linked with monodentate $\mathrm{PO}_{4}{ }^{3-}$ and $\mathrm{U}(\mathrm{vI})$ species immobilized on clay minerals. ${ }^{29}$ Different secondary $\mathrm{U}$ species, i.e. uranocircite, and metazeunerite, dominate in the area of the Krunkelbach $\mathrm{U}$ deposit resulting after high $\mathrm{Ba}$ (higher $\mathrm{Ba} / \mathrm{Ca}$ ratio) and As contents in the groundwaters and their preferential fixation on altered uraninite. ${ }^{17,22}$ Further oxidative dissolution of uraninite from the microcavities and surface of the rock favors the release of these elements as well as $\mathrm{P}, \mathrm{W}, \mathrm{Pb}, \mathrm{Si}$ and $\mathrm{Fe}$ into the environment. ${ }^{65}$

\section{Conclusion}

Herein, we demonstrated how a combination of synchrotron and laboratory techniques can be utilized for a rapid elemental and mineralogical analysis of altered granitic rock systems without any complicated sample preparation and treatment procedures. Based on this analytical approach, a multiphase uranium mineralisation with cuprosklodowskite coatings and metazeunerite-metatorbernite microcrystalline species were identified. We showed the evidence for the microscale chemical and morphological heterogeneities of the metazeunerite-metatorbernite phase and their alteration. The $\sim 200 \mu \mathrm{m}$ size microcrystalline species collected from the surface of a rock are close to metazeunerite with high As/P ratio and exhibit altered, uneven morphology, while the species collected from the cavities of the rock is a well-preserved phase close to metatorbernite. A high degree of the phase alteration in surface species could be attributed to local geochemical conditions i.e., continuous interaction with the intruding groundwaters. In the recent study, metazeunerite-metatorbernite species has been identified in the soils at another abandoned $U$ mine in the Southern UK, attributed to intensive U mining activities. ${ }^{18}$ In this context, the stability of the secondary phases and estimation of their long-term behaviour become crucial for predicting the mobilization of radionuclides. Additional research can be focused on the investigation of the thermodynamic and degradation properties of the metazeunerite-metatorbernite phases with varying As and $\mathrm{P}$ contents, ${ }^{66}$ and analysis of $\mathrm{U}$ and As speciation in soil systems. The Cu-bearing uranyl arsenatephosphate mineralization potentially occurs in several hydrothermal type locations including abandoned U mines, geological formations considered for the storage of SNF around hydrothermal $\mathrm{U}$ deposits of the orogenic belt in Western and Central Europe. ${ }^{40}$ A similar experimental methodology 
described and introduced here can be utilized for the investigation of various environmental systems, i.e., sediments and soils. However, some geological systems with low contents of environmental radionuclides might need additional experimental approach: selective chemical leaching and radiometric analysis.

\section{Statement of contributions}

I. P. and K. O. K. designed research; I. P., S. B., I. S., D. D., L. V., D. B., R. v. S. performed $\mu$-XRF and $\mu$-XANES measurements; K. O. K., S. B., R. v. S., I. S. measured HERFD-XANES; I. P. and S. H. performed SEM-EDX analysis; L. A. performed theoretical calculations of XANES spectra for U mineral references; R. J. B. provided U mineral references; J. G. measured $\mu$-PXRD; I. P. measured Raman; I. P., S. B., R. J. B, S. N. K. and K. O. K. wrote the manuscript.

\section{Conflicts of interest}

Authors declare no conflict of interests.

\section{Acknowledgements}

This work was supported by European Research Council (ERC) Starting Grant No 759696. I. P. is grateful to Steffen Möckel (Alpha Geophysik $\mathrm{GmbH}$ ) for providing granite sample. K. O. K. and S. N. K. acknowledge support by the Ministry of Education and Science of the Russian Federation under grant no. 075-152019-1891.

\section{Notes and references}

1 R. Hähne and G. Altmann, Principles and Results of Twenty Years of Block-Leaching of Uranium Ores by Wismut GmbH, Germany, IAEA-TECDOC-720, IAEA, Wien, 1993.

2 N. Florea and G. Duliu Octavian, J. Hazard. Toxic Radioact. Waste, 2013, 17, 230-236.

3 A. Abdelouas, Elements, 2006, 2, 335-341.

4 J.-C. Petit, J. Geochem. Explor., 1992, 46, 1-33.

5 R. J. Baker, Coord. Chem. Rev., 2014, 266-267, 123-136.

6 P. C. Burns, R. C. Ewing and A. Navrotsky, Science, 2012, 335, 1184.

7 R. C. Ewing, Nat. Mater., 2015, 14, 252.

8 B. E. Burakov, M. I. Ojovan and W. E. Lee, Crystalline Materials for Actinide Immobilisation, Imperial College Press, 2010.

9 M. Laraia, in Radioactive Waste Management and Contaminated Site Clean-Up, ed. W. E. Lee, M. I. Ojovan and C. M. Jantzen, Woodhead Publishing, 2013, pp. 301326, DOI: 10.1533/9780857097446.1.301.

10 W. Miller, R. Alexander, N. Chapman, J. C. McKinley and J. A. T. Smellie, Geological Disposal of Radioactive Wastes and Natural Analogues, Elsevier Science, 2000.

11 P. C. Burns, Can. Mineral., 2005, 43, 1839-1894.

12 P. Gamaletsos, The Handbook of Environmental Chemistry, 2016, vol. 40, pp. 77-113.
13 I. A. Katsoyiannis, S. J. Hug, A. Ammann, A. Zikoudi and C. Hatziliontos, Sci. Total Environ., 2007, 383, 128-140.

14 Y. Wang, P. Le Pape, G. Morin, M. P. Asta, G. King, B. Bártová, E. Suvorova, M. Frutschi, M. Ikogou, V. H. C. Pham, P. L. Vo, F. Herman, L. Charlet and R. Bernier-Latmani, Environ. Sci. Technol., 2018, 52, 34313439.

15 E. Curti, A. Puranen, D. Grolimund, D. Jädernas, D. Sheptyakov and A. Mesbah, Environ. Sci.: Processes Impacts, 2015, 17, 1760-1768.

16 Y. He, Y. Xiang, Y. Zhou, Y. Yang, J. Zhang, H. Huang, C. Shang, L. Luo, J. Gao and L. Tang, Environ. Res., 2018, 164, 288-301.

17 B. A. Hofmann, MRS Proceedings, 2011, 127, 921.

18 C. L. Corkhill, D. E. Crean, D. J. Bailey, C. Makepeace, M. C. Stennett, R. Tappero, D. Grolimund and N. C. Hyatt, npj Mater. Degrad., 2017, 1, 19.

19 M. A. Denecke, A. Somogyi, K. Janssens, R. Simon, K. Dardenne and U. Noseck, Microsc. Microanal., 2007, 13, 165-172.

20 R. J. P. Driscoll, D. Wolverson, J. M. Mitchels, J. M. Skelton, S. C. Parker, M. Molinari, I. Khan, D. Geeson and G. C. Allen, RSC Adv., 2014, 4, 59137-59149.

21 J. Essilfie-Dughan, M. J. Hendry, J. Warner and T. Kotzer, in The New Uranium Mining Boom: Challenge and Lessons learned, ed. B. Merkel and M. Schipek, Springer Berlin Heidelberg, Berlin, Heidelberg, 2012, pp. 325-334, DOI: 10.1007/978-3-642-22122-4_38.

22 B. Hofmann, Genese, Alteration und rezentes Fliess-System der Uranlagerstätte Krunkelbach (Menzenschwand, Südschwarzwald), NAGRA Technischer Bericht 88-30, 1989.

23 U. Noseck, T. Brasser, J. Suksi, V. Havlová, M. Hercik, M. A. Denecke and H.-J. Förster, Phys. Chem. Earth, 2008, 33, 969-977.

24 M. Paul, T. Metschies, M. Frenzel and J. Meyer, in The New Uranium Mining Boom: Challenge and Lessons learned, ed. B. Merkel and M. Schipek, Springer Berlin Heidelberg, Berlin, Heidelberg, 2012, pp. 689-699, DOI: 10.1007/978-3-64222122-4_79.

25 U. Schwertmann, Plant Soil, 1991, 130, 1-25.

26 R. Vochten and A. Goeminne, Phys. Chem. Miner., 1984, 11, 95-100.

27 C. Frondel, Systematic mineralogy of uranium and thorium, Report 1064, 1958.

28 E. Faulques, N. Kalashnyk, F. Massuyeau and D. L. Perry, RSC Adv., 2015, 5, 71219-71227.

29 A. Tayal, S. D. Conradson, A. Kanzari, F. Lahrouch, M. Descostes and M. Gerard, RSC Adv., 2019, 9, 11762-11773.

30 H. A. Thompson, G. E. Brown, Jr and G. A. Parks, Am. Mineral., 1997, 82, 483-496.

31 N. P. Edwards, S. M. Webb, C. M. Krest, D. van Campen, P. L. Manning, R. A. Wogelius and U. Bergmann, J. Synchrotron Radiat., 2018, 25, 1565-1573.

32 C. Hall, P. Barnes, J. K. Cockcroft, S. D. M. Jacques, A. C. Jupe, X. Turrillas, M. Hanfland and D. Häusermann, Anal. Commun., 1996, 33, 245-248. 
33 E. A. Stefaniak, A. Alsecz, R. Frost, Z. Máthé, I. E. Sajó, S. Török, A. Worobiec and R. Van Grieken, J. Hazard. Mater., 2009, 168, 416-423.

34 K. Maher, J. R. Bargar and G. E. Brown, Inorg. Chem., 2013, 52, 3510-3532.

35 L. Newsome, K. Morris and J. R. Lloyd, Chem. Geol., 2014, 363, 164-184.

36 J. P. McKinley, J. M. Zachara, C. Liu, S. C. Heald, B. I. Prenitzer and B. W. Kempshall, Geochim. Cosmochim. Acta, 2006, 70, 1873-1887.

37 C. A. Cravotta and G. R. Watzlaf, in Handbook of Groundwater Remediation using Permeable Reactive Barriers, ed. D. L. Naftz, S. J. Morrison, C. C.Fuller and J. A.Davis, Academic Press, San Diego, 2003, pp. 19-66, DOI: 10.1016/B978-0125135634/50006-2.

38 C. C. Fuller, J. R. Bargar, J. A. Davis and M. J. Piana, Environ. Sci. Technol., 2002, 36, 158-165.

39 B. Hofmann and J. Eikenberg, Econ. Geol., 1991, 86, 10311049.

$40 \mathrm{H}$. W. Bültemann and W. D. Bültemann, The Uranium Deposit Krunkelbach in the Southern Black Forest, IAEATECDC-361, Federal Republic of Germany, 1986.

41 S. Bauters, P. Tack, J. H. Rudloff-Grund, D. Banerjee, A. Longo, B. Vekemans, W. Bras, F. E. Brenker, R. van Silfhout and L. Vincze, Anal. Chem., 2018, 90, 2389-2394.

42 A. Hammersley, J. Appl. Crystallogr., 2016, 49, 646-652.

$43 \mathrm{~K}$. Walenta, Tschermaks mineralogische und petrographische Mitteilungen, 1964, vol. 9, pp. 111-174.

44 S. V. Krivovichev and J. Plášil, in Uranium - Cradle to Grave, ed. P. C. Burns and G. E. Sigmon, The Mineralogical Association of Canada, Winnipeg, MB, 2013, pp. 43-49.

45 K. Walenta, F. Hatert, T. Theye, F. Lissner and K. Röller, Eur. J. Mineral., 2009, 21, 515-520.

46 C. Den Auwer, E. Simoni, S. Conradson and C. Madic, Eur. J. Inorg. Chem., 2003, 3843-3859, DOI: 10.1002/ejic.200300093.

47 K. O. Kvashnina and A. C. Scheinost, J. Synchrotron Radiat., 2016, 23, 836-841.

48 I. Pidchenko, K. O. Kvashnina, T. Yokosawa, N. Finck, S. Bahl, D. Schild, R. Polly, E. Bohnert, A. Rossberg, J. Göttlicher, K. Dardenne, J. Rothe, T. Schäfer, H. Geckeis and T. Vitova, Environ. Sci. Technol., 2017, 51, 2217-2225.

49 J. Rothe, M. Altmaier, R. Dagan, K. Dardenne, D. Fellhauer, X. Gaona, E. González-Robles Corrales, M. Herm,
O. K. Kvashnina, V. Metz, I. Pidchenko, D. Schild, T. Vitova and H. Geckeis, Geosciences, 2019, 9, 91.

50 I. Pidchenko, F. Heberling, K. O. Kvashnina, N. Finck, D. Schild, E. Bohnert, T. Schäfer, J. Rothe, H. Geckeis and T. Vitova, J. Phys. Conf. Ser., 2016, 712, 012086.

51 A. Manceau, M. Enescu, A. Simionovici, M. Lanson, M. Gonzalez-Rey, M. Rovezzi, R. Tucoulou, P. Glatzel, K. L. Nagy and J.-P. Bourdineaud, Environ. Sci. Technol., 2016, 50, 10721-10729.

52 B. Lafuente, R. T. Downs, H. Yang and N. Stone, Highlights in Mineralogical Crystallography, 2015, DOI: 10.1515/ 9783110417104-003.

53 R. L. Frost, M. L. Weier and M. O. Adebajo, Thermochim. Acta, 2004, 419, 119-129.

54 S. L. Korzeb, E. E. Foord and F. E. Lichte, Can. Mineral., 1997, 35, 135-144.

55 R. Finch and T. Murakami, in Uranium: Mineralogy, Geochemistry, and the Environment, 1999, vol. 38, ch. 91-180.

56 T. Murakami, T. Ohnuki, H. Isobe and T. Sato, Am. Mineral., 1997, 82, 888-899.

57 B. J. Merkel, in The New Uranium Mining Boom: Challenge and Lessons learned, ed. B. Merkel and M. Schipek, Springer Berlin Heidelberg, Berlin, Heidelberg, 2012, pp. 627-633, DOI: 10.1007/978-3-642-22122-4_72.

58 M. Birke, U. Rauch, H. Lorenz and R. Kringel, J. Geochem. Explor., 2010, 107, 272-282.

59 K. Bender, Herkunft und Entstehung der Mineral- und Thermalwässer im nördlichen Schwarzwald, PhD thesis, University of Heidelberg, 1995.

60 N. Belai, M. Frisch, E. S. Ilton, B. Ravel and C. L. Cahill, Inorg. Chem., 2008, 47, 10135-10140.

61 P. C. Burns, R. J. Finch, F. C. Hawthorne, M. L. Miller and R. C. Ewing, J. Nucl. Mater., 1997, 249, 199-206.

62 D. H. Phillips, D. B. Watson and Y. Roh, Environ. Sci. Technol., 2007, 41, 7653-7660.

63 J. E. Stubbs, D. C. Elbert, D. R. Veblen and C. Zhu, Environ. Sci. Technol., 2006, 40, 2108-2113.

64 L. Krall, B. Sandström, E.-L. Tullborg and L. Z. Evins, Appl. Geochem., 2015, 59, 178-188.

65 J. Finch Robert, L. Miller Mark and C. Ewing Rodney, Radiochim. Acta, 1992, 58-59, 433.

66 J. Kulaszewska, S. Dann, P. Warwick and C. Kirk, Philos. Trans. R. Soc. A, 2019, 377, 20180242. 